\title{
CULTURAL CAPITAL AND READING PERFORMANCE OF THE ROMANIAN STUDENTS IN POST-COMMUNIST ROMANIA. CAN THE GAPS STILL BE RECOVERED?
}

\section{Georgiana CICEO}

Associate Professor, $\mathrm{PhD}$,

Faculty of European Studies, Babeș-Bolyai University Cluj-Napoca, gciceo@yahoo.com

\section{DOI:10.24193/OJMNE.2017.24.01}

\begin{abstract}
The Program for International Student Assessment (PISA) has indicated over the years modest improvements in the reading performances of the Romanian students. Nevertheless, Romania still lags far behind the Organization for Economic Co-operation and Development (OECD) average and remains among the laggards at EU level. In the present paper we discuss, based on PISA evaluations of 2009 and 2015, the relation between cultural capital and reading achievement among Romanian students. We come to the conclusion that the transformations undergone by the Romanian society in the post-communist period contributed to a continuous and steady decline in the importance of cultural capital with slim chances to redress this tendency despite the strong interconnection between cultural capital and reading performance.
\end{abstract}

Keywords: PISA, cultural capital, reading performance, Romania, quality of education

Almost three decades ago Romania embarked itself on the transition from a communist regime whose distinctive features included "public/state ownership rather than private, an ideological emphasis on equality rather than freedom, an economy organized on a plan, central control and direction rather than through a market, and a collectivist and public form of personal integration rather than an individualist one" (Lane, 2014: 11). Along the way Romania has undergone profound political, social and economic transformations. The 
Issue no. $24 / 2017$

process of European integration interacted with the one of domestic makeover and contributed significantly to the shape of the new regime. Romanian education system could not escape these transformative changes although it proved to be more resilient as, in spite of a protracted crisis that began in the 1980's and overwhelming difficulties and restrictions, proved not to be "entirely inefficient, inert, or anachronistic" since it could produce yearly international 'Olympics' in core academic disciplines like math, physics, computer sciences or winners of international contests in arts performances (Bîrzea, 1997: 322). In the Romanian context, the efforts for the country's modernization that got underway at the end of the 19th and the start of the 20th century gave rise to appropriate and stable institutions, like the education system, which due to the structure and organization of the studies, school orientation and curriculum organization, interest in the situation of the teaching staff, fostering of research (Reianu, 2014: 300) could not be entirely corrupted by communism (Bîrzea, 1997: 323). After 1989, Romania, like most of the Central and Eastern European countries with the notable exceptions of Slovenia, Hungary, the Czech Republic, and Poland, has not proceeded to systemic reforms. It rather opted for a reform by infusion characterized by the observance of the principles of subsidiarity not only through decentralization, but also through vertical devolution (to local public authorities, communities) and horizontal devolution (to civil society); increased importance attached to the roles of experts and professors in all project development stages. This reform strategy was motivated, on the one hand, by the acknowledged failures of the top-down reform, and, on the other hand, by the underdeveloped state of the civil society that proved to be unable to unleash a bottom-up reform (Bîrzea, 1997: 323-324).

The Romanian educational system seeks to focus on the formation of competences, understood in the sense of knowledge, qualifications, motivations, attitudes, emotions, as well as other social and behavioral components appropriate to the context that a person needs for its own personal and professional development, for its social inclusion and integration into the labor market. However, in a world undergoing rapid change as a result of globalization and modernization, the society as a whole and each of its members in particular are exposed to many challenges. Swift technological changes in the workplace and in day-to-day life lead to the need to process a considerable amount of information. As a consequence, reading 
Issue no. $24 / 2017$

competences become essential for engaging in social, economic and cultural life, and achieving individual aspirations. Educational systems have the mission to provide a framework for lifelong learning to the society in order to be able to meet the challenges of tomorrow. Its members need to be prepared to respond successfully to complex requirements, in various contexts, by mobilizing their cognitive and psychological resources. In this context, the formation of reading skills acquires special significance as reading is indispensable for learning in all disciplines and is an essential element in any professional activity.

The performance of the Romanian education system in an increasingly competitive environment can be best assessed by PISA tests performed by OECD that have proved to be a reliable source of information for monitoring the outcomes of education systems in terms of student achievement, within a common internationally agreed framework, and a useful tool for refining educational policies. They are and meant to assess the competences of 15-years old students in reading, math and science. Conducted every three years since 2000, they focus each time round on one of the three above-mentioned areas of interest, whereby the other two remain in the background. They are based on the idea of competences gained by the students until the end of the compulsory education in most OECD countries and understood as "ability to meet complex demands, by drawing on and mobilising psychosocial resources (including skills and attitudes) in a particular context (OECD, 2005: 4). It is true that over the years the capacity of these tests to provide credible information about the success of the younger generation has come to be questioned on the ground that education is more than doing good on tests, that correct interpretation of the results of standardized tests with such a high degree of complexity is generally extremely difficult to accomplish, or that their stake is only the assessment of knowledge. It is accurate to stress outright that the tests cannot capture the ability of young people to interact with others, to control and resolve conflicts, to respect and appreciate other values, i.e. essential skills for the social and professional integration of young people although a number of studies in the literature have highlighted the interrelationships between academic competences and social and emotional skills (Oberle et al, 2014: 146-147). Moreover, several studies have shown that PISA tests have a great predictability ability on adolescent future success (Schleicher, 2007: 354-356). 
Issue no. $24 / 2017$

The reading skills assessed through PISA refer to the ability to access, control, integrate and evaluate information, to think creatively, to formulate hypotheses, to communicate effectively one's own ideas. So the stake is not primarily to test the ability to absorb information, but especially to extrapolate it and use it in new situations, similar to those of real life. The reading performance framework has constantly evolved over the years from the need to enrich the concept of reading literacy and align it with the requirements of the current digital age. OECD studies refer to "understanding, use, reflection and engagement with written text in order to achieve personal goals, develop knowledge and potential and participate in society" (OECD, 2016: 48-50). ${ }^{1}$

Without any intention to overdo the value of these tests, we have to acknowledge the fact that the PISA tests have from the beginning highlighted the modest level of knowledge of the Romanian students in reading, math and sciences. As shown in Table 1 the Romanian students underperform in all three areas of evaluation and their results are well below the OECD average and remain far behind the top performers and the other EU Member States. Looking only to the last assessment, the one from 2015, the performances of the Romanian education system can be regarded as close to those of EU countries like Bulgaria, Cyprus and Malta, and at an international level similar to those of Uruguay, United Arab Emirates, Turkey, Costa Rica, Trinidad and Tobago, Montenegro and Colombia. Although Romania is praised for taking effective measures for improving performance, our country's position in the ranking has not made any notable progress.

\footnotetext{
${ }^{1}$ Reading skills of young people are assessed on an ascending scale from 1 to 6 . The critical threshold is considered to be the bottom line for level 2 (i.e. 407 score points), regarded as correspondent for the basic level of knowledge, necessary to be reached by students until the completion of their compulsory education. It assumes that the student is able to locate one or more information that may require deduction and fulfillment of multiple conditions, recognize the main idea of a text, understand relationships or build meaning within a particular part of the text when the information is not obvious. At the same time, the student needs to make simple deductions, comparisons or oppositions based on a single feature of the text, draw parallels with nontextual knowledge, using personal experiences and on the basis of individual attitudes. Below this threshold are levels $1 \mathrm{a}$ and $1 \mathrm{~b}$, which correspond to a totally unsatisfactory level of knowledge, while at the opposite end there are levels 5 (scores between 626 and 698) and 6 (scores higher than 698), indicating excellence in reading. These students are considered to have the ability to locate and organize more hidden information in the text, to identify truly relevant information, to critically evaluate or formulate hypotheses based on specialized knowledge, to fully understand a text whose content is not familiar to them.
} 
Issue no. $24 / 2017$

Table 1 - Romanian results in PISA testing

\begin{tabular}{|c|c|c|c|c|c|c|c|c|c|c|c|c|c|c|c|}
\hline & \multicolumn{3}{|c|}{2000} & \multicolumn{3}{|c|}{2006} & \multicolumn{3}{|c|}{2009} & \multicolumn{3}{|c|}{2012} & \multicolumn{3}{|c|}{2015} \\
\hline & $\mathbf{R}$ & $\mathrm{M}$ & $\mathrm{S}$ & $\mathrm{R}$ & $\mathrm{M}$ & $\mathbf{S}$ & $\mathbf{R}$ & $\mathrm{M}$ & $S$ & $\mathrm{R}$ & $\mathbf{M}$ & $S$ & $\mathrm{R}$ & $\mathrm{M}$ & $\mathbf{S}$ \\
\hline $\begin{array}{l}\text { Score } \\
\text { points }\end{array}$ & 428 & - & - & 396 & 415 & 418 & 424 & 427 & 428 & 438 & 436 & 439 & 437 & 418 & 435 \\
\hline $\begin{array}{l}\text { OECD } \\
\text { average }\end{array}$ & 496 & - & - & 496 & 494 & 502 & 493 & 496 & 500 & 496 & 494 & 501 & 493 & 490 & 493 \\
\hline $\begin{array}{l}\text { Difference } \\
\text { in score } \\
\text { points to } \\
\text { OECD } \\
\text { average }\end{array}$ & 68 & - & - & 100 & 79 & 84 & 69 & 69 & 72 & 58 & 58 & 62 & 56 & 72 & 58 \\
\hline Top score & 525 & - & - & 546 & 544 & 563 & 556 & 600 & 575 & 570 & 613 & 580 & 535 & 564 & 556 \\
\hline $\begin{array}{l}\text { Difference } \\
\text { in score } \\
\text { points to top } \\
\text { position }\end{array}$ & 97 & - & - & 150 & 129 & 145 & 132 & 173 & 147 & 132 & 177 & 141 & 98 & 146 & 121 \\
\hline $\begin{array}{l}\text { Position } \\
\text { among } \\
\text { participating } \\
\text { countries }\end{array}$ & $\begin{array}{l}-4 ! \\
43\end{array}$ & - & - & $\begin{array}{l}51 / \\
57\end{array}$ & $\begin{array}{l}44 / \\
57\end{array}$ & $\begin{array}{l}47 / \\
57\end{array}$ & $\begin{array}{l}49 / \\
65\end{array}$ & $\begin{array}{l}48 / \\
65\end{array}$ & $\begin{array}{c}47 / \\
65\end{array}$ & $\begin{array}{l}51 / \\
65\end{array}$ & $\begin{array}{l}45 / \\
65\end{array}$ & $\begin{array}{l}50 / \\
65\end{array}$ & $\begin{array}{l}48 / \\
72\end{array}$ & $\begin{array}{l}45 / \\
72\end{array}$ & $\begin{array}{l}48 / \\
72\end{array}$ \\
\hline $\begin{array}{l}\text { Position } \\
\text { among EU } \\
\text { countries }^{5 / .}\end{array}$ & $\begin{array}{c}17 / \\
17\end{array}$ & - & - & $\begin{array}{l}26 / \\
26\end{array}$ & $\begin{array}{l}25 / \\
26\end{array}$ & $\begin{array}{l}25 / \\
26\end{array}$ & $\begin{array}{l}25 / \\
26\end{array}$ & $\begin{array}{l}25 / \\
26\end{array}$ & $\begin{array}{l}25 / \\
26\end{array}$ & $\begin{array}{l}26 / \\
27\end{array}$ & $\begin{array}{c}25 / \\
27\end{array}$ & $\begin{array}{l}26 / \\
27\end{array}$ & $\begin{array}{l}27 / \\
28\end{array}$ & $\begin{array}{c}26 / \\
28\end{array}$ & $\begin{array}{l}27 / \\
28\end{array}$ \\
\hline
\end{tabular}

Source: OECD The OECD Programme for International Student Assessment (PISA) www.pisa.oecd.org.

Notes:

1/. $\mathrm{R}$ = reading, $\mathrm{M}=$ math, $\mathrm{S}=$ science

2/. Romania did not participate in the 2003 evaluation.

3/. The bold characters indicate the area in focus at each evaluation and the results achieved by the Romanian students in this area.

4/. Results from PISA 2000 for Romania were, for technical reasons, not available when the report was assembled, and included later in an addendum to the main report.

5/. Results for Malta are available since 2015, whereas for Cyprus since 2012.

For the purpose of this research, we intend only to discuss the results obtained by the Romanian students in reading at the 2009 evaluation that focused on this competence and the one from 2015 as this is the last one before the next year's assessment concentrated again on reading. Whenever possible we will bring in inputs from the 2000 assessment whose main target was yet again reading, but employed slightly different techniques of evaluation. We proceed from the assumption that reading is the basis of learning in all disciplines and an essential element in any professional activity. In a world undergoing rapid change as a result of globalization and modernization, society as a whole and each of its members in particular are exposed to many challenges. Fast technological changes in the workplace and in day-today life lead to the need to process a considerable amount of information. Under these circumstances, reading skills become essential for engaging in social, economic and cultural 
life, and achieving individual aspirations. Educational systems have the mission to help train lifelong learners to meet the challenges of tomorrow. This further raises the question of their preparation to respond successfully to complex requirements, in diverse contexts, by mobilizing their cognitive and psychological resources.

The main research question revolves around the role of cultural capital in reinforcing reading achievements and the way this was affected by the transformations undergone by the Romanian society in the post-communist period. We consider the concept of cultural capital, as coined by Pierre Bourdieu in 1977 and later developed in his further research, of particularly usefulness for explaining unequal intellectual accomplishment of children stemming from different socio-economic backgrounds. As such, it comprises the social assets of a person (education, intellect, skills, style of speech and dress, etc.) that uphold its social mobility in a complex society and represents a break with the assumption that the academic success or failure depends only on natural aptitudes and the amount of educational investment. The cultural capital coexists according to Bourdieu in three forms - an embodied state that combines the hereditary intellectual legacy with the acquisition of scholarly and social skills throughout the entire period of socialization, an objectified state that refers to the number of properties that help a person wield strengths and obtain profits in the artistic field, scientific field, etc. and an institutionalized state that exist in the form of academic qualifications (Bourdieu, 1986). The scientific literature on cultural capital indicates two different approaches to its conceptualization - a narrower one emphasizing the exclusiveness of high status cultural resources (i.e. high culture extracurricular activities such as music, dance, drama lessons, etc.) and a broader one in the sense of a comprehensive toolkit of skills, styles, and habits that people use in everyday life to construct designs of action. In an international context, the explanatory power of cultural capital (especially in its objectified form) for reading achievements varied depending on the features of the societal structure and its educational system (Bodovski et al, 2016: 2-3).

In an Eastern European setting, the resort to cultural capital proves to offer certain benefits as the education systems still bear features that can be ascertained to their communist past. These regimes aimed to create a supposedly equal society, one in which there are no classes and each person is seen as part of the collective whole, working toward the end goal 
Issue no. $24 / 2017$

of political, economic, and social equality. The Communist regimes did provide free, universal, and compulsory education. Admissions to elite schools and universities (with the exception of politically sensitive specializations such as law, philosophy, or sociology) was open to all, education was affordable, state grants to both schools and students were relatively significant. Illiteracy was virtually eradicated, but education was highly regimented and "the curriculum was strictly controlled, as all-important decisions were centralized" (Reisz, 2006: 74). By controlling the information that reached the classroom as well as the teaching methods, the Communist regimes sought to imbue students with Marxist dogma training them to be future, faithful Communists. Throughout the education process students were not encouraged to think critically on their own, but rather to commit to memorize and deliver. Dissatisfaction with the education system remained high among those seeking spiritual and intellectual freedom and/or planning to specialize in neglected, if not entirely forbidden or heavily distorted fields (Antohi, 2004). After the shift, reforms took place that altered curriculum, added supplementary options for textbooks, endorsed activities that develop critical thinking and practical skills and increased teacher autonomy. However, the process of reform has been slow and current educational practices are still dealing with the effects of Communism (Istrate et al, 2006).

As far as the reading skills of the Romanian students are concerned, despite the outstanding performances of the few Romanian students participating in international Olympiads in core academic disciplines or international contests in arts acts, the bulk of the Romanian students achieved results that place them either slightly above the minimum line or outright beneath this. Cumulating the average score with an even more worrying one emerging from the same tests, namely, that more than one in three secondary school graduates is functionally illiterate (in the sense that although is capable to read, still is unable to understand the message of the text, see Table - 2), we can say that we are faced with a systemic problem whose main roots need to be identified and properly addressed especially if we take into consideration that a number of other national tests only confirm the results of the PISA assessments (Centrul Naţional de Evaluare și Examinare, 2016: 9-12). From the point of view of increasing the achievement of Romanian students, absolute priority must be given to improving performance at both extremes. On the one hand, there is the problem of 
Issue no. $24 / 2017$

recovering those with poor results, since up to Level 2 in PISA assessment Romanian scores are well above the OECD average. On the other hand, from Level 3 upwards Romanian students' scores are well beneath OECD average this meaning that, given the way in which the Romanian education system works, not even this group of outstanding students can be properly valued and it is completely out of the question to consider that it can stimulate other able students to reach the peak of their performance especially if we take into consideration that according to former Romanian Minister for Education Mircea Miclea, in any education system, no matter how performing or poorly performing this may be, we have a proportion of $3-5 \%$ students with exceptional results, who "are their own product" and not the product of the system (Pantazi, 2013b).

Table 2 - Percentage of Romanian students at each grade level. Percentage of Romanian low achievers and top performers in reading in comparison to the OECD average

\begin{tabular}{|c|c|c|c|c|c|c|c|c|c|c|}
\hline & $\begin{array}{c}\text { Below } \\
\text { Level } \\
1 \mathrm{~b} \\
\text { (below } \\
262.04 \\
\text { score } \\
\text { points) }\end{array}$ & 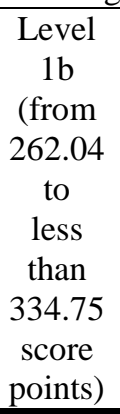 & 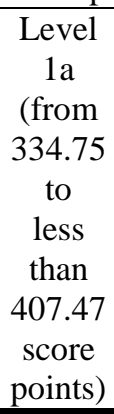 & $\begin{array}{c}\text { Bellow } \\
\text { Level } \\
\mathbf{2} \\
\text { (less } \\
\text { than } \\
409.54 \\
\text { score } \\
\text { points) }\end{array}$ & $\begin{array}{c}\text { Level } \\
2 \\
\text { (from } \\
407.47 \\
\text { to } \\
\text { less } \\
\text { than } \\
480.18 \\
\text { score } \\
\text { points) }\end{array}$ & $\begin{array}{l}\text { Level } \\
3 \\
\text { (from } \\
480.18 \\
\text { to } \\
\text { less } \\
\text { than } \\
552.89 \\
\text { score } \\
\text { points) }\end{array}$ & $\begin{array}{c}\text { Level } \\
4 \\
\text { (from } \\
552.89 \\
\text { to } \\
\text { less } \\
\text { than } \\
625.61 \\
\text { score } \\
\text { points) }\end{array}$ & $\begin{array}{c}\text { Above } \\
\text { Level } \\
\mathbf{5} \\
\text { (above } \\
613.33 \\
\text { score } \\
\text { points) }\end{array}$ & $\begin{array}{c}\text { Level } \\
5 \\
\text { (from } \\
625.61 \\
\text { to } \\
\text { less } \\
\text { than } \\
698.32 \\
\text { score } \\
\text { points) }\end{array}$ & $\begin{array}{c}\text { Level } \\
6 \\
\text { (above } \\
698.32 \\
\text { score } \\
\text { points) }\end{array}$ \\
\hline $\begin{array}{l}\text { Proficiency } \\
\text { levels in } \\
\text { PISA 2009 }\end{array}$ & $4.1 \boldsymbol{\Delta}$ & $12.7 \boldsymbol{\Delta}$ & $23.6 \mathbf{\Delta}$ & $40.4 \Delta$ & $31.6 \mathbf{\Delta}$ & $21.2 \nabla$ & $6.1 \nabla$ & $0.7 \nabla$ & $0.7 \nabla$ & $0.0 \nabla$ \\
\hline $\begin{array}{l}\text { OECD } \\
\text { average in } \\
2009\end{array}$ & 1.1 & 4.6 & 13.1 & 18.8 & 24.0 & 28.9 & 20.7 & 7.4 & 6.8 & 0.8 \\
\hline $\begin{array}{l}\text { Proficiency } \\
\text { levels in } \\
\text { PISA 2015 }\end{array}$ & $3.7 \Delta$ & $11.6 \mathbf{\Delta}$ & $23.4 \boldsymbol{\Delta}$ & $38.7 \Delta$ & $29.5 \Delta$ & $21.3 \nabla$ & $8.4 \nabla$ & $2.0 \nabla$ & $1.8 \nabla$ & $0.2 \nabla$ \\
\hline $\begin{array}{l}\text { OECD } \\
\text { average in } \\
2015\end{array}$ & 1.3 & 5.2 & 13.6 & 20.1 & 23.2 & 27.9 & 20.5 & 8.3 & 7.2 & 1.1 \\
\hline
\end{tabular}

Source: OECD (2010) PISA 2009 Results. Volume I: What Students Know and Can Do, Paris: OECD Publishing, p. 194. https://www.oecd.org/pisa/pisaproducts/48852548.pdf .

OECD (2016) PISA 2015 Results. Volume I: Excellence and Equity in Education, Paris: OECD Publishing, pp. 373-374. http://dx.doi.org/10.1787/9789264266490-en .

Beyond these figures, which are in themselves significant enough, we need to view these results also in a European context. While it is true that the cultural capital has a certain bearing on the level of education, the former's association with a higher level of Europeanness in the sense of shared values associated with collective identity constructions 
Issue no. $24 / 2017$

about Europe, and at the same time with "common cultural traditions and historical experiences, common development of distinct constitutional and political principles, a definite sense about what constitutes Europe's 'others"' (Păun, Ciceo, 2010: 95) or an increased role of interculturalism in European integration (Dan, 2014) remains still to be debated. Examining the association between education and the sense of a European identity, Best (2012: 217-227) came to the conclusion that although higher levels of education may elevate elites' Europeanness and impact positively on their attachment to Europe as welleducated individuals possess increased cognitive abilities and social competences that allow them to better interact in complex institutional and cultural settings, its impact on common citizens' support for European integration according to Inglehart's theory of cognitive mobilization remains limited.

The effects of cultural capital on school attainments has been studied over the years from different perspectives. A number of studies offered comparative analyses on the nature of this relation (Barone, 2006; Xu, Hampden-Thompson, 2012; Byun et al, 2012; Bodovski et $a l, 2016)$ based primarily on the results of PISA evaluations. There were also attempts to analyze this relation in a national setting either based on country-level surveys (Crook, 1997; Sullivan, 2001; De Graaf et al, 2001; Yamamoto, Brinton, 2010) or based on comparisons with other countries based again on information from PISA database (Pavlovic-Babic, Baucal, 2011; Byun et al, 2012). Based on data from five national representative and fully comparable surveys conducted in 1993 in Bulgaria, Czech Republic, Hungary, Poland and Slovakia, Kraaykamp, Nieuwbeerta (2000) studied new forms of political and cultural transmission in former socialist countries. Subsequently, we intend to explore, based on the poor results of the Romanian students in PISA evaluations why cultural capital in all its three forms remains a relevant concept for explaining these results in the context of the fundamental changes undergone by the Romanian education system as a result of the transition from a communist past. As already mentioned, for reasons related to the limits imposed on this article we will focus the entire discussion on how the reading skills come to be influenced by this transformed concept of cultural capital, being convinced that these can contribute to the remedy other counter-performances of the Romanian education system, such as, the share of school leavers before graduation (in Romania 19.1\%, compared to the EU 
target of $11 \%$ ), the employment rate of graduates, especially those with high school education (Romania $59.8 \%$ of the EU target of $71 \%$ ) or the percentage of those enrolled in university studies (25.6\% in Romania, compared to the EU target of 38.7\%) (European Commission, 2016) and bridging the profound fault line that separates the country from the rest of Europe.

Although visibly not entirely unambiguous in construction, cultural capital proved to be practical enough for researchers and generated a good deal of empirical work, the most important part of it being focused on the relation between cultural capital and educational attainment. In general, education assumes the existence of an embodied cultural capital produced by family upbringing, but how parents pass on this non-material asset to their children needed to be tested as Bourdieu "assumes much of what he sets out to prove" (Sullivan, 2002: 153-155). Further on, Bourdieu presumed that cultural capital facilitates the acquisition of educational credentials which further influence the way in which riches and supremacy are transmitted between generations, but again was ambiguous in explaining the mechanisms behind this process. As the definition of the concept lacks the necessary clarity it has been operationalized in different ways (Lareau, Weiniger, 2003: 570-573). Of relevance for the present discussion are those studies that link children's cultural capital to their parents', and especially those that focus on reading behavior of both children and parents (De Graaf, 1986; Aschaffenburg, Maas, 1996; Crook, 1997; De Graaf et al, 2000; Sullivan, 2001). These studies have indicated that reading is strongly associated to academic success.

That is why improving reading skills would be an important premise for reviving the parameters in which Romania's educational system country operates since we live in an era when, thanks to modern technologies, information is relatively easy to access for everyone. We have to start from the assumption that in their future adult life today's teenagers will face the most diverse forms of text from which they will have to extract relevant information on certain topics important to them in order to assimilate new content or solving complex tasks. What makes the difference between a competent adult capable of engaging in society and one less prepared for this is the ability to process, analyze, interpret and apply information.

Reading skills are essential to any kind of vocational training, they are critical for school/academic performance in all disciplines, they contribute decisively to the lifelong learning effort and ultimately determine the social and professional insertion of anyone. 
However, reading skills cannot be equated with knowing how to read. As a rule, they sweep across a broader spectrum - from the ability to detect significant details and to integrate and interpret ideas by referring to other relevant texts to the impossibility of explicitly recognizing, locating and reproducing information in a single text. The absence of these abilities deprive a reader of properly collecting the fruits of the effort to go through a text. Theories of reading have demonstrated the development of these skills in stages, each one characterized by different acquisition models. It is generally believed that children first "learn to read", and only thereafter begin to "read to learn" (Clarke et al, 2014: 13). In other words, early school years are essential for the acquisition and development of reading techniques. Matthew's Effect ascertained that their absence by the end of the primary cycle, when the reading techniques are assumed to have already been acquired, can trigger for children a spiral of negative effects, since after this moment it becomes somewhere between very difficult and almost impossible to recover the gap separating these children from their school mates and engage consistently in understanding a written text (Ibidem, 25). In our view, it is equally important to take into account that reading skills need to be expanded, deepened and refined throughout the entire education cycle. By the time of leaving the school students need to be equipped with a set of knowledge, skills, and strategies to decode the written text. Only this way can they realize their life goals and to be able to cope with the demands of the real world without difficulty.

Reading stimulates creativity, empathy and tolerance towards others, is essential for overcoming cynicism and selfishness, understanding of values, communication, impartial and objective search for truth, critical thinking, plays an extremely important role in forming a capacity to react to the blind power of tradition or abuse of power by the authorities (Dumitru, 2016). By reading a text must an individual has to be able to identify the main subject, appreciate the general relevance of the text, assess the credibility of the information, discern between relevant and irrelevant information, establish connections with information from other sources, critically analyze the content, draw the correct conclusions. In order to understand the meaning of a text it is necessary to acquire decoding and understanding techniques influenced by cognitive, motivational, socio-cultural factors. Reading is in itself a transformative experience. In the effort to understand the meaning of a text, only part of the 
information comes from the text itself, the rest is the result of the interaction between the text and the reader. Reading skills take into account the interactive nature of reading and the constructive nature of meaning-building processes, as the reader generates meanings in response to the text message, using the knowledge accumulated up to that point, and a series of reader keys that are professionally formed, socially and/or culturally. Therefore, reading skills should be supported by general culture, cognitive development, reading motivation, understanding of the interactive nature of any reading.

Texts can be extremely diverse - longer or shorter, richer or poorer in informative content, with a simpler or more complex construction. In general, it is considered that the development of the ability to engage in the penetration of the written text is acquired at all disciplines studied in school, but it is a priority for language courses (maternal, foreign, etc.). This is done in steps, through specific methods and techniques (Hadârcă, 2015). Regardless of the discipline, the main pedagogical resource for the formation of these competences is the written text. However, at present written text is not only in printed or hand-written format. More and more written text is presented in electronic format, contains hyperlinks and is accompanied by visual images such as diagrams, photos, pictures, tables, and graphics, and requires specific decoding techniques. Being literate today means being able to use blogs, text messages, search engines, social networks, internet communication tools, mobile apps. Tomorrow, this IT resource inventory that needs to be mastered will expand in order to meet requirements that are still hard to predict (Leu et al, 2011: 6). Under these circumstances, the content of reading skills is constantly changing.

In general, electronic texts are nonlinear, interactive, contain multi-media representations, open the way to extremely varied formulas of text interaction. Whereas the conventional texts present the information in the form in which it was organized by the author, and the reader, even when deciding to run over the pages or browse through the text, can only peruse the content of a text with a linear format and a relatively rigid structure, the electronic format almost invites the readers to build their own version based on the information they make available with search engines or multi-media inserts, they can engage in dialogue with the author or other readers, can express their opinions (Coiro, 2003: 460). In this fundamentally changed context, beset with both opportunities and challenges for our 
ability to become active members of the society, the arsenal of tools needed to support reading skills is radically changing, as it becomes imperative to critically evaluate the sources from which information is retrieved, locate relevant information, draw parallels with real life situations, manage databases, use search engines, cope with information validation strategies. The role of the teacher remains essential, even if his mission changes fundamentally, and his support by the family and community through the promotion of appropriate policies and the involvement of non-governmental actors (foundations, civic organizations, networks of actors involved in reading promotion) needs to be reinforced. Moreover, OECD has opened since 2009 the possibility of evaluating students' performance in electronic format, and by 2018 it would impose this type of assessment on future tests, as in the 21 st century, reading skills should include both printed and electronic text This means that students need to be familiar with IT equipment and master techniques for navigating and searching information in hypertext (i.e. text containing hyperlinks and non-sequential structured pages). For students to learn the necessary cognitive and metacognitive techniques, the teachers themselves have to review their own training so that they can build the reading skills of students in all disciplines. The curriculum is bound to be brought into line with the new role of technology and revised in a way that encourages transdisciplinarity. A greater autonomy for schools and teachers in organizing study material would become an imperative must. By performing systematic research projects, performance can be assessed, compared, and used to identify good practice. In a European context, this process is favored by the regulatory and competitive pressure created on authorities to adopt competitive educational policies (Lawn, Normand, 2015: 8-10).

Romanian education system has undergone major changes since 1989. There is now a growing shift from teacher-centered to student-centered teaching, as officials hope to move away from a reproductive-learning approach to one that focused more on problem-solving and empower children to think critically. Nevertheless, the process is very slow. It was found that even after the curriculum had been changed for several years, only twenty-five percent of the teachers indicated a dramatic change in their instruction methods (Istrate et al, 2006). This basically means that the reading skills are still to a large extent generated by methods inappropriate for allowing students to cope with the demands of the digital age. 
Issue no. $24 / 2017$

A number of studies have indicated that "children seem to benefit more from their parents' linguistic and cognitive skills" (De Graaf et al, 2000: 11) and that the effect of parental reading on the students' academic performance is significant yet less important than the effect of financial resources (Crook, 1997). PISA surveys have confirmed that in the case of Romania the below-average reading performance is associated with an average impact of socio-economic background and the figures presented in the report are further compounded by low enrollment rates (OECD, 2010).

\section{Conclusions}

Reading skills play an essential role in integrating and actively involving all of its members. Developing the necessary reading skills for deciphering the sense of the written text remains a major desideratum, but we must keep in mind that the format in which the written text is presented has experienced spectacular developments in the digital age. Without losing relevance, the techniques, strategies, knowledge needed to understand the printed text must now be enriched to effectively explore the resources offered by the Internet. The two text formats are not mutually exclusive and must be exploited effectively. The latest simulation of the National Evaluation exam for $8^{\text {th }}$ grade students (at the end of their compulsory education) has shown how even a relatively innocuous printed text can create major problems for students insufficiently prepared to decode meaning, capitalize on information and establish connections ${ }^{2}$.

For Romania, overcoming the modest results achieved so far in international tests, means that it needs to review the way in which reading skills are formed in school, given the pedagogical and psychological dimension in which these skills are formed, and the impossibility of limiting them to intuition or sterile engagement. Otherwise, Romanian education will be condemned to remain inefficient, irrelevant, unfair and of poor quality (Miclea et al, 2007: 7-9). If we also take into account the gaps that need to be recovered, the

\footnotetext{
${ }^{2}$ In 2017, 8th grade students had to analyze in a simulation for the Romanian National Language Examination a non-literary text and establish who is the organizer of an exhibition of chess pieces in a museum - a teacher as private collector and owner of the chess pieces or the museum as a public institution whose mission is to bring together and display valuable art collections (Ministry of National Education, the National Evaluation and Examination Center, 2017).
} 
Issue no. $24 / 2017$

urgency of the measures becomes even more prominent as otherwise we will continue to sell illusions of competence and we will end up not counting on the global labor market (Pantazi, 2013a). So far, apparently, it seems to be a moving target to which we are heading, but cannot hope to reach it very soon.

\section{Bibliography}

1. ANTOHI, S. (2004) Higher Education and the Post-Communist Generation of Students. In: Carey, F.H. (ed.), Romania since 1989: politics, economics, and society, Lanham, Maryland: Lexington Books, pp. 335-353.

2. BARONE, C. (2006) Cultural Capital, Ambition and the Explanation of Inequalities in Learning Outcomes. A Comparative Analysis. Sociology 40 (6), pp. 1039-1058.

3. BÂRZEA, C. (1997) The Dilemmas of the Reform of Romanian Education: Shock Therapy, the Infusion of Innovation, or Cultural Decommunization?. Higher Education in Europe, XXII(3), pp. 321-327.

4. BEST, H. (2012) Elite foundation of European integration: a causal analysis. In: BEST, H., LENGYEL, G., VERZICHELli, L. (ed.) The Europe of Elites. A Study into the Europeanness of Europe's Political and Economic Elites, Oxford: Oxford University Press, pp. 208-234.

5. BODOVSKI, K., JEON, H., BYUN, S. (2016) Cultural capital and academic achievement in post-socialist Eastern Europe. British Journal of Sociology of Education, 38(6), 2016, pp. 1-18.

6. BOURDIEU, P. (1986) Forms of Capital. In: RICHARDSON, J.G. (ed.) Handbook of theory and research for the sociology of education, New York, NY: Greenwood Press, pp. 241-258.

7. BYUN, S., SCHOFER, E., KIM, K.K. (2012) Revisiting the Role of Cultural Capital in East Asian Educational Systems: The Case of South Korea. Sociology of Education 85 (3), pp. 219-239. 
Issue no. $24 / 2017$

8. CENTRUL NAȚIONAL DE EVALUARE ȘI EXAMINARE (2016) Raport Național. Analiza rezultatelor Evaluării naționale la finalul clasei a VI-a. Proba: Limbă și comunicare.

http://rocnee.eu/sites/default/files/2017-

09/Raport_EN_VI_2016_Limba_si_comunicare.pdf, [accessed on 28/11/2017].

9. ClARKE, P.J.; TRUElOVE, E.; HUlME, C.; SNOWLING, M.J. (2014) Developing Reading Comprehension, Chichester: Wiley Blackwell.

10. COIRO, J. (2003) Exploring Literacy on the Internet: Reading Comprehension on the Internet: Expanding Our Understanding of Reading Comprehension to Encompass New Literacies. The Reading Teacher, 56(5), pp. 458-464. organize

11. CROOK, C. J. (1997) Cultural Practices and Socioeconomic Attainment: The Australian Experience. Westport, Connecticut: Greenwood Press.

12. DAN, H. S. (2014) The Role of Interculturalism in European Integration. Studia Universitatis Babeș-Bolyai. Studia Europaea, 2, pp. 131-142.

13. DAN, H. S. (2017) Is social progress subject to cultural influences? Arguments for considering cultural characteristics as inputs for social policy design and implementation. On-line Journal Modelling the New Europe, 22, pp. 104-122.

14. DE GRAAF, N. D., DE GRAAF, P., KRAAYKAMP, G. (2000). Parental Cultural Capital and Educational Attainment in the Netherlands: A Refinement of the Cultural Capital Perspective. Sociology of Education, 73, 92-111.

15. DUMITRU, M. (2016) Sfârşitul umanioarelor? De ce mai avem nevoie de educaţie umanistă în universități?. Vatra, $21 \quad$ iunie 2016, https://revistavatra.org/2016/06/21/mircea-dumitru-sfarsitul-umanioarelor-de-ce-maiavem-inca-nevoie-de-educatie-umanista-in-universitati/, [accessed on 8/11/2017].

16. EUROPEAN COMMISSION (2016) Education and Training Monitor 2016 Romania. https://ec.europa.eu/education/sites/education/files/monitor2016-ro_en.pdf, [accessed on 8/11/2017]. 
Issue no. $24 / 2017$

17. HADÂRCĂ, M. (2015) Competența de lectură - concept, structură şi mediu de formare. Limba română,

$\mathrm{XXV}(3-4)$.

http://www.limbaromana.md/index.php?go=articole\&printversion=1\&n=3167, [accessed on $10 / 11 / 2017]$.

18. ISTRATE, O.; NOVEANU, G.; SMITH, T.M. (2006) Exploring sources of variation in Romanian science achievement. Prospects, 36(4), pp. 475-496.

19. KOGAN, I.; GEBEL, M.; NOELKE, C. (2012) Educational Systems and Inequalities in Educational Attainment in Central and Eastern European Countries. Studies of Transition States and Societies, 4(1), pp. 69-83.

20. KRAAYKAMP, G., NIEUWBEERTA, P. (2000) Parental Background and Lifestyle Differentiation in Eastern Europe: Social, Political, and Cultural Intergenerational Transmission in Five Former Socialist Societies. Social Science Research, 29 (1), pp. 92 122.

21. LANE, D. (2014) The capitalist transformation of state socialism: the making and breaking of state socialist society, and what followed, New York: Routledge.

22. LAREAU, A., WEININGER, E.B. (2003) Cultural Capital in Educational Research: A Critical Assessment. Theory and Society, 32(5/6), pp. 567-606.

23. LAWN, M.; NORMAND, R. (2015) Introduction. In: LAWN, M., NORMAND, R. (ed.), Shaping of European Education. Interdisciplinary approaches, New York: Routledge, pp. $1-13$.

24. LEU, D.J.; McVERRY, J.G.; O’BYRNE, W.I.; KIILI, C.; ZAWILINSKI, L.; EVERETTCACOPARDO, H.; KENNEDY, C.; FORZANI, E. (2011) The New Literacies of Online Reading Comprehension: Expanding the Literacy and Learning Curriculum. Journal of Adolescent \& Adult Literacy, 55(1), pp. 5-14.

25. MICLEA, M. et al (2007) România educaţiei, România cercetării. Raportul Comisiei Prezidenţiale pentru analiza şi elaborarea politicilor din domeniile educaţiei şi cercetării http://old.presidency.ro/static/rapoarte/Raport_CPAEPDEC.pdf. 
Issue no. $24 / 2017$

26. MINISTERUL EDUCAȚIEI NAȚIONALE, CENTRUL NAŢIONAL DE EVALUARE ȘI EXAMINARE, CENTRUL NAȚIONAL PISA (2012), Raportul Centrului Naţional PISA pentru ciclul de 2011-2012. http://www.rocnee.eu/Files/CNEE_\%20PISA_2012_15.10.2015_FINAL.pdf, [accessed on $10 / 11 / 2017]$.

27. MINISTERUL EDUCAŢIEI NAŢIONALE, CENTRUL NAŢIONAL DE EVALUARE ŞI EXAMINARE (2017), Evaluarea Naţională pentru elevii clasei a VIII-a. Anul şcolar 2016 - 2017. Probă scrisă: Limba şi literatura română. http://subiecte2017.edu.ro/2017/simulare/simulare_en_VIII/, [accessed on 10/11/2017].

28. OBERLE, E.; SCHONERT-REICHL, K.A.; HERTZMAN, C.; ZUMBO, B.D. (2014), Social-emotional competencies make the grade: Predicting success in early adolescence. Journal of Applied Developmental Sociology, 35, pp. 138-147.

29. OECD (2005), The definition and selection of key competencies. Executive Summary. https://www.oecd.org/pisa/35070367.pdf, [accessed on 15/11/2017].

30. OECD (2010) PISA 2009 Results. Volume I: What Students Know and Can Do, Paris: OECD Publishing. https://www.oecd.org/pisa/pisaproducts/48852548.pdf, [accessed on $15 / 11 / 2017]$.

31. OECD (2016) PISA 2015 Results. Volume I: Excellence and Equity in Education, Paris: OECD Publishing. http://dx.doi.org/10.1787/9789264266490-en, [accessed on $15 / 11 / 2017]$.

32. OECD (2016), PISA 2015 Assessment and Analytical Framework: Science, Reading, Mathematic and Financial Literacy, OECD Publishing, Paris, http://dx.doi.org/10.1787/9789264255425-en, [accessed on 15/11/2017].

33. PANTAZI, R. (2013a) Mircea Miclea: Învățământul gimnazial e în metastază. Trebuie scurtate vacanțele și intensificată munca cu elevii în școală, altfel nu vom mai conta pe piața globală a muncii. Avem cel mai scurt an școlar din Europa!. Hotnews, 3 iulie 2013 http://www.hotnews.ro/stiri-esential-15118869-care-sunt-efectele-unui-examen-subiecte- 
Issue no. $24 / 2017$

$\underline{\text { usoare-mircea-miclea-discuta-online-joi-ora-15-30-despre-controversele-evaluarea- }}$ nationala-2013.htm, [accessed on 10/11/2017].

34. PANTAZI, R. (2013b) Rezultate PISA 2012. Mircea Miclea: Lehamitea profesorilor îi contaminează pe elevi, care învață cu aceeași lehamite cu care li se predă. Hotnews, 5 decembrie 2013 http://www.hotnews.ro/stiri-esential-16139127-care-este-explicatiarezultatelor-romaniei-testul-pisa-2012-unde-gresim-sunt-aproape-toate-celelalte-tarieuropene-mai-bune-decat-noi-educatie.htm, [accessed on 10/11/2017].

35. PAVLOVIC-BABIC, D.; BAUCAL, A. (2011) The big improvement in PISA 2009 reading achievements in Serbia: improvement of the quality of education or something else?. CEPS Journal, 1(3), pp. 53-74.

36. PĂUN, N., CICEO, G. (2010) The Limits of Europeanness. Can Europeanness Stand Alone as the Only Guiding Criterion for Deciding Turkey's EU Membership?. Eurolimes - Journal of the Institute for Euroregional Studies, 9, pp. 90-105.

37. REIANU, D. G. (2014) Modernizarea României în primul deceniu interbelic. Învățământul românesc în presa partidelor politice, Cluj-Napoca: EFES.

38. REIANU, D. G., BARNA, C. (2014) Europeanization of Regional Indentities in Romania. Case Study: The Land of Moți, In: Studia Universitatis Babeș-Bolyai - Studia Europaea, 2, pp. 63-78.

39. REISZ, R.D. (2014) Romania Is Oscillating Between Centralism and Autonomy. European Education, 38(1), pp. 73-84

40. SCHLEICHER, A. (2007) Can competences assessed by PISA be considered the fundamental school knowledge 15 year olds should possess?. Journal of Education Change, 8, pp. 349-357.

41. SUlLIVAN, A. (2001) Cultural Capital and Educational Attainment. Sociology, 34 (4), 893-912.

42. SULliVAN, A. (2002) Bourdieu and Education: How Useful is Bourdieu's Theory for Researchers?. The Netherland's Journal of Social Sciences, 38(2), pp. 144-166. 
Issue no. $24 / 2017$

43. XU, J., HAMPDEN-THOMPSON, G. (2012) Cultural Reproduction, Cultural Mobility, Cultural Resources, or Trivial Effect? A Comparative Approach to Cultural Capital and Educational Performance. Comparative Education Review 56 (1), pp. 98-124.

44. YAMAMOTO, Y., BRINTON, M.C. (2010) Cultural Capital in East Asian Educational Systems: The Case of Japan. Sociology of Education, 83 (1), pp. 67-83. 